\title{
Factors Influencing Legacy Pollutant Accumulation in Alpine Osprey: Biology, Topography, Or Melting Glaciers?
}

\author{
John E. Elliott, ${ }^{\dagger} *$ Joshua Levac, ${ }^{\ddagger}$ Mélanie F. Guigueno, ${ }^{\ddagger}$ D. Patrick Shaw, ${ }^{\S}$ Mark Wayland, ${ }^{\Perp}$ \\ Christy A. Morrissey, ${ }^{\perp}$ Derek C. G. Muir, ${ }^{\#}$ and Kyle H. Elliott ${ }^{\ddagger}$ \\ ${ }^{\dagger}$ Wildlife \& Landscape Science Directorate, Environment Canada, Delta, BC, Canada, V4K 3N2 \\ ${ }^{\ddagger}$ Department of Biological Sciences, University of Manitoba, Winnipeg, Canada, R3T 2N2 \\ ${ }^{\S}$ Water Science and Technology Directorate, Environment Canada, Vancouver, BC, Canada,, V6C 3S5 \\ "Canadian Wildlife Service, Environment Canada, Saskatoon, SK, Canada, S7N $0 \times 4$ \\ ${ }^{\perp}$ Department of Biology, University of Saskatchewan, Saskatoon, SK, Canada, S7N 5E2 \\ \#Water Science \& Technology Directorate, Environment Canada, Burlington, ON, Canada L7R 4A6
}

\section{Supporting Information}

\begin{abstract}
Persistent organic pollutants (POPs) can be transported long distances and deposited into alpine environments via cold trapping and snow scavenging processes. Here we examined biotic and abiotic factors determining contaminant variability of wildlife in alpine ecosystems. We measured POPs in eggs and plasma of an apex predator, the osprey (Pandion haliaetus) breeding in 15 mountainous watersheds across a broad latitudinal, longitudinal and altitudinal range in western Canada. After accounting for proximate biotic factors such as trophic level $\left(\delta^{15} \mathrm{~N}\right)$ and carbon source $\left(\delta^{13} \mathrm{C}\right)$, variability in contaminant concentrations, including $\Sigma \mathrm{DDT}$ (sum of trichlorodiphenylethane-related compounds), toxaphene, hexachlorobenzene (HCB), total chlordane, and $\Sigma$ PCBs (polychlorinated biphenyls) in osprey tissues was explained by interactions among relative size of watersheds, water bodies, elevation, and glacial input. $\Sigma$ DDT in nestling plasma, for example, decreased with lake elevation, probably as a result of local past inputs from agricultural or public health usage at lower altitude sites. In contrast, toxaphene, never used as an insecticide in western Canada, increased with elevation and year-round snow and ice cover in both plasma and eggs, indicating long-range atmospheric sources as dominant for toxaphene. Lower chlorinated PCBs in plasma tended to decrease with elevation and ice cover consistent with published data and model outcomes. Temporal trends of POPs in osprey eggs are coincident with some modeled predictions of release from melting glaciers due to climate change. Currently we suggest that contaminants largely are released through annual snowpack melt and deposited in large lower elevation lakes, or some smaller lakes with poor drainage. Our study highlights the importance of understanding how biological processes integrate physical when studying the environmental chemistry of wildlife.
\end{abstract}

\section{INTRODUCTION}

Deposition of atmospherically transported volatile contaminants by trapping in cold environments, as a result of either increased latitude ${ }^{1}$ or altitude $^{2}$ is well documented. That process, when coupled with the efficient scavenging of these chemicals through adsorption to snow crystals ${ }^{3}$ can result in accumulation of persistent organic pollutants (POPs) in arctic and alpine environments. ${ }^{4,5}$ Recent global warming trends have caused the contraction of many of the world's large ice masses. ${ }^{6,7}$ Assessment and modeling of the impact of global warming trends and melting of polar and glacial ice on accumulation of contaminants have yielded varying predictions as to the degree and direction of patterns and trends. ${ }^{8-10}$ However, recent studies in alpine environments indicate stored POPs are released into receiving waters from glacial melting. ${ }^{11-17}$

Concentrations of specific compounds in fish tissue, such as more volatile PCBs (polychlorinated biphenyls) and hexachlorocyclohexane $(\mathrm{HCH})$, increase with latitude across
Canada. ${ }^{18,19}$ Other chemicals, particularly DDT (trichlorodiphenylethane), total PCBs and toxaphene in fish samples from alpine and remote northern lakes exceed consumption guidelines for humans and wildlife. ${ }^{20,21}$ However, in contrast to the Arctic, where numerous studies have examined uptake and transfer of contaminants to fish-eating top predators, 4,22 there are no such studies from alpine regions.

Western Canada affords an interesting opportunity to examine the influence of topography and ecological variation on contaminant accumulation in the alpine. The region is dissected by a number of mountain ranges up to $4000 \mathrm{~m}$ altitude running north to south, and is the first landfall for pollutants transported atmospherically from the increasingly industrialized economies of Asia. ${ }^{23}$ The osprey (Pandion

Received: April 18, 2012

Revised: July 25, 2012

Accepted: August 9, 2012

Published: August 9, 2012 
haliaetus) is an obligate piscivore and a common breeding species on lakes and rivers across much of the globe. Ospreys integrate exposure from the entire food chain, and were selected here and elsewhere as effective sentinels of environmental contamination. ${ }^{24-27}$ As top predators, they are among the more highly exposed wildlife in most systems; DDE (dichlorodiphenylethylene), PCBs and PBDEs (polybrominated diphenyl ethers) have all been associated with biological effects in ospreys. ${ }^{26,28-31}$ Although ospreys are long distance migrants and winter in Latin American countries that continued to use organochlorine pesticides after they were banned in North America, contaminant levels in satellite-tracked osprey eggs have been related to breeding and not to winter exposure for many of the same nests as the present study. ${ }^{25}$

To examine topographical and ecological influences on contaminants in osprey, from 1999 to 2003 we measured organochlorine pesticides and PCBs in egg and plasma samples. Because POPs and other contaminants biomagnify within food chains and disperse more uniformly in aquatic compared with terrestrial ecosystems, we measured $\delta^{15} \mathrm{~N}$ as a measure of trophic level and $\delta^{13} \mathrm{C}$ as indication of carbon input which has been effectively applied in other aquatic and marine birds. ${ }^{32-35}$

We employed an information theoretic approach to examine the importance of biotic factors: trophic level, carbon source, and topographic abiotic factors: altitude, lake area, water basin size, water body type (river, reservoir or natural lake), percent of glacier in watersheds and ratio of lake size to watershed size along with physical-chemical parameters in determining contaminant levels. We hypothesized that contamination would be greater for birds feeding at higher trophic levels, and in drainage basins at increased elevation and with more coverage in permanent snow and ice.

\section{MATERIALS AND METHODS}

Calculation of Geographic Features. The Spatial Analyst toolbox and Hydrology toolset in ARCGIS 9.2 were used to measure the size (area) of 24 watershed drainage basins and of local osprey foraging lakes and rivers within the Canadian Cordillera (ESRI, www.esri.com). Elevation ( $\mathrm{m}$ ) of osprey nest location and watershed area $\left(\mathrm{km}^{2}\right)$ were calculated using the digital elevation model and glacier data archived at NRC Geomatics Canada. ${ }^{36,37}$ Glacial areas $\left(\mathrm{km}^{2}\right)$ were calculated using current glacier extents. All data was reprojected into the same coordinate system UTM Zone $11 \mathrm{~N}, \mathrm{NAD} 83$ to ensure area conformity. Postprocessing of data with the Hydrology toolset required sink-filling using the sink tool (see ref 38 for the algorithm) and the calculation of slope, aspect, flow direction and accumulation of water, and stream networks using flow direction and accumulation, watershed and stream network algorithms. ${ }^{39-41}$ Once watersheds were developed, areas of both watersheds and glaciers were calculated using the script within ARCGIS 9.2.

Sample Collection. From 1999 to 2003, we collected 88 eggs (one per nest) from incubating ospreys, plasma and feather samples from 70 nestling ospreys from 59 nests, and 11 plasma samples from adult ospreys nesting in 15 watersheds of the Canadian Cordillera in British Columbia and the Yukon (Figure 1). The sampled watersheds varied from small, 1170 $\mathrm{km}^{2}$ of the Pitt to very large of the Williston, $66,623 \mathrm{~km}^{2}$ (Table 1). Lake area varied over several orders in magnitude from the $6 \mathrm{~km}^{2}$ of Athabasca Lake to $1660 \mathrm{~km}^{2}$ of the Williston reservoir. Elevation ranged from sea level at Pitt Lake to $1210 \mathrm{~m}$ at Athabasca Lake. The glaciated area of the studied watersheds

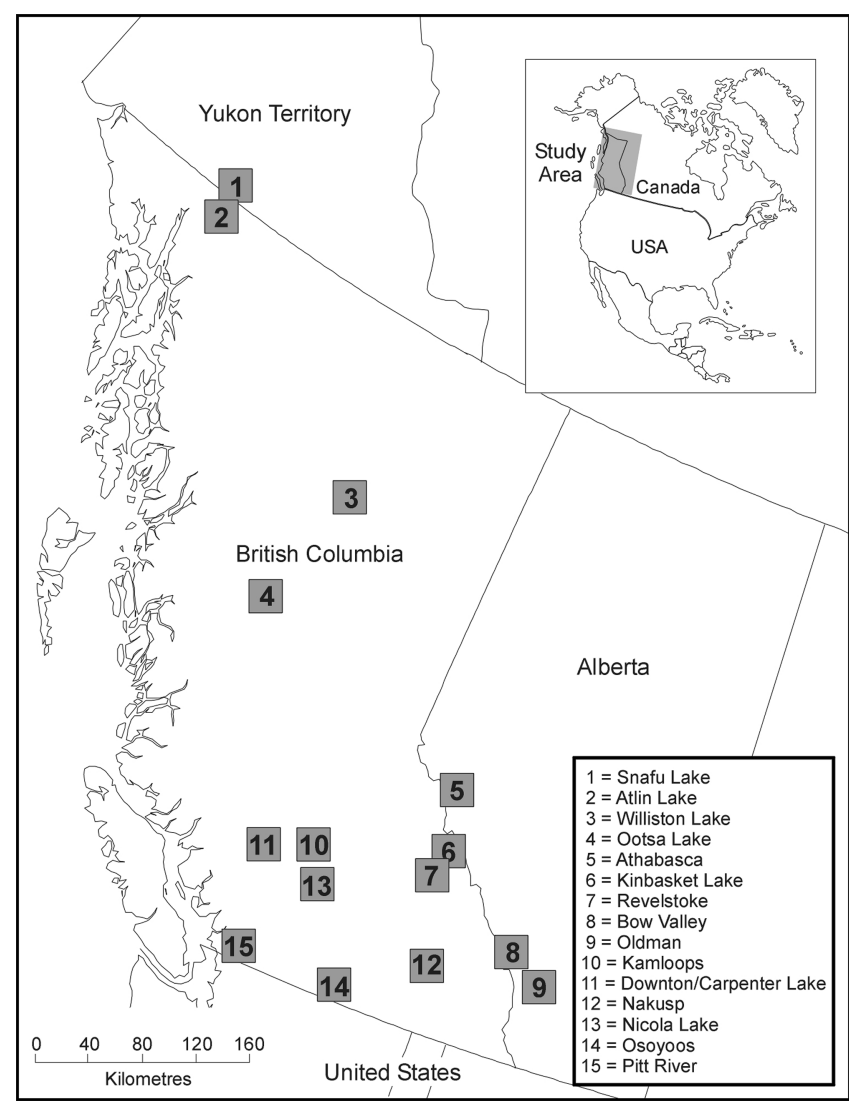

Figure 1. Locations where osprey eggs and plasma samples were collected, 1999-2003, in British Columbia, Alberta, and the Yukon Canada.

was somewhat polarized, eight sites having only zero to one percent glaciated and five watersheds with 9 to $12 \%$.

We captured adult ospreys using a domed noose carpet (balchatri) placed over the active nest or modified dho-ghaza mist nets with a tethered Great Horned Owl, Bubo virginianus, as a lure bird and attached a satellite transmitter to their back. ${ }^{24}$ Each bird was weighed, measured, and banded with a U.S. Fish and Wildlife Service band on one leg and a red alphanumeric band on the other leg. Eggs and chicks were sampled by climbing into the nest platform. At some nests, it was possible to safely remove an egg but not a chick for blood sampling, thus sample sizes are fewer for chicks. Further details on nest access, nestling and adult sampling, and transmitter attachment procedures were described previously. ${ }^{23,24}$

Contaminant Analysis. (See Supporting Information for more detailed methods). Organochlorine pesticides and PCBs in eggs and plasma were analyzed at the National Wildlife Research Center (Ottawa, ON, Canada) using gas chromatography with an electron capture detector (GC-ECD) as described previously. ${ }^{27}$ Briefly, lipid and moisture concentration was determined gravimetrically, samples were cleaned and analyzed along with blanks and reference samples in a HewlettPackard model 5890 Series II Plus gas chromatograph with 63Ni-ECD detector, HP-3396 integrator, HP-7673A autosampler (Hewlett-Packard, Palo Alto, CA).

Toxaphene measurements were conducted at the Canada Centre for Inland Waters (Burlington, ON, Canada). Gas chromatography-mass spectrometry was carried out using a Hewlett-Packard mass selective detector (HP5973 MSD) operated in negative ion mode. 
Table 1. Summary Information on the Western Canadian Watersheds for Lakes and Rivers Included in the Study and Geometric Mean (Wet Weight) Concentrations of Contaminants in Eggs and Nestling Plasma of Ospreys, 1999-2002 ${ }^{a}$

\begin{tabular}{|c|c|c|c|c|c|c|c|c|c|c|c|c|c|c|c|c|c|}
\hline \multirow[b]{2}{*}{ watershed } & \multirow[b]{2}{*}{$\begin{array}{l}\text { watershed } \\
\text { area }\left(\mathrm{km}^{2}\right)\end{array}$} & \multirow{2}{*}{$\begin{array}{c}\text { lake } \\
\text { area } \\
\left(\mathrm{km}^{2}\right)\end{array}$} & \multirow[b]{2}{*}{$\begin{array}{c}\% \\
\text { glac. }\end{array}$} & \multirow[b]{2}{*}{$\begin{array}{l}\text { elev. } \\
(\mathrm{m})\end{array}$} & \multirow[b]{2}{*}{$\delta^{15} \mathrm{~N}$} & \multirow[b]{2}{*}{$\delta^{13} \mathrm{C}$} & \multirow[b]{2}{*}{$N^{b}$} & \multicolumn{2}{|c|}{$\Sigma$ DDTs (ng/g) } & \multicolumn{2}{|c|}{$\begin{array}{l}\text { toxaphene } \\
\text { (ng/g) }\end{array}$} & \multicolumn{2}{|c|}{$\begin{array}{c}\sum \text { chlordanes } \\
(\mathrm{ng} / \mathrm{g})\end{array}$} & \multicolumn{2}{|c|}{$\mathrm{HCB}(\mathrm{ng} / \mathrm{g})$} & \multicolumn{2}{|c|}{$\Sigma$ PCBs (ng/g) } \\
\hline & & & & & & & & egg & plas & egg & plas & egg & plas & egg & plas & egg & plas \\
\hline Athabasca & 2505 & 6 & 9 & 1210 & 9.3 & -26.6 & 5,5 & 288 & 2.6 & 177 & 0.0 & 5.1 & 0.9 & 0.9 & 0.1 & 307 & 7.7 \\
\hline Atlin & 8820 & 586 & 9 & 675 & 9.6 & -24.3 & 6,4 & 716 & 6.7 & 22.1 & 0.3 & 3.9 & 0.5 & 0.8 & 0.3 & 178 & 2.5 \\
\hline Bow & 2596 & 8 & 0.3 & 1546 & 11.4 & -27.3 & 7,5 & 905 & 7.6 & 62.0 & 1.2 & 7.2 & 0.4 & 1.2 & 0.1 & 436 & 11.4 \\
\hline Columbia & 16330 & 24 & 1.3 & 808 & 8.8 & -26.6 & 7,6 & 575 & 5.5 & $\mathrm{NA}^{c}$ & 2.6 & 1.4 & 0.4 & 0.4 & 0.2 & 109 & 5.5 \\
\hline $\begin{array}{l}\text { Downton } \\
\text {-Carpenter }\end{array}$ & 2014 & 45 & 5 & 676 & 9.7 & -27.0 & 6,3 & 924 & 5.1 & NA & 5.8 & 2.5 & 0.4 & 0.7 & 0.3 & 672 & 20.7 \\
\hline Kinbasket & 14773 & 402 & 11.4 & 745 & $\mathrm{NS}^{d}$ & N.S. & 6,0 & 747 & NS & NA & NS & 3.3 & 1.0 & 1.0 & $\mathrm{NS}^{d}$ & 182 & NS \\
\hline Nicola & 4296 & 24 & 0 & 645 & NS & N.S. & 6,3 & 775 & 7.8 & 238 & 0.0 & 19.6 & 0.3 & 2.5 & 0.5 & 1420 & 12.6 \\
\hline Oldman & 8808 & 6 & 0 & 1264 & 13.1 & -28.2 & 4,3 & 714 & 5.1 & 23.5 & 0.0 & 22.4 & 0.3 & 1.4 & 0.1 & 826 & 7.7 \\
\hline Ootsa & 13225 & 365 & 1 & 852 & 10.6 & -29.2 & 7,6 & 979 & 8.7 & 12.1 & 0.3 & 1.2 & 0.4 & 0.2 & 0.3 & 38.2 & 1.7 \\
\hline Osoyoos $^{e}$ & 8203 & 369 & 0 & 305 & 13.9 & -26.3 & 4,5 & 2660 & 104 & NA & 1.7 & 5.0 & 0.3 & 0.6 & 0.2 & 487 & 11.1 \\
\hline Pitt & 1170 & 70 & 12 & 10 & 10.0 & -25.7 & 5,2 & 760 & 4.1 & NA & 3.2 & 1.1 & 0.7 & 0.7 & 0.4 & 485 & 11.1 \\
\hline Revelstoke & 5253 & 66 & 11 & 594 & N.S. & N.S. & 4,0 & 493 & NS & 11.9 & NS & 9.6 & 0.8 & 1.3 & NS & 250 & NS \\
\hline Snafu & 1508 & 9 & 0 & 793 & 10.4 & -26.9 & 1,1 & 1790 & 29.2 & 42.0 & 0.0 & 2.7 & 0.3 & 0.5 & 0.1 & 23.0 & 4.5 \\
\hline $\begin{array}{l}\text { Upper } \\
\text { Arrow }\end{array}$ & 7643 & 228 & 4 & 431 & 8.1 & -27.3 & 5,1 & 347 & 3.1 & NA & 0.9 & 0.6 & 0.4 & 0.5 & 0.2 & 120 & 28.2 \\
\hline Williston & 66623 & 1660 & 0 & 690 & N.S. & N.S. & 7,0 & 42 & NS & 17.2 & NS & 1.3 & 0.3 & 0.6 & NS & 82.6 & NS \\
\hline
\end{tabular}

${ }^{a}$ Stable isotope values $\left(\delta 15 \mathrm{~N}\right.$ and $\delta 13 \mathrm{C}$ ) are averages for nestling plasma. ${ }^{b}$ Number of nests (number of eggs, number of chicks). ${ }^{c} \mathrm{NA}$, not analyzed. ${ }^{d} \mathrm{NS}$, not sampled. ${ }^{e}$ For calculation of lake and watershed area, we used the whole Okanagan Lake system, given the past area of orchards and pesticide use throughout that lake system, and Osoyoos' location near the bottom of that drainage.

Results are presented on a wet weight basis throughout.

Stable Isotope Analysis. Egg and plasma samples were dried, $1 \pm 0.2 \mathrm{mg}$ encapsulated in tin, and sent to University of California (Davis, CA) stable isotope facility. Lipids were not removed from plasma and egg samples due to expected low lipid levels. Samples were first loaded into tin cups and combusted in a Robo-Prep elemental analyzer (Europa Scientific) at $1200{ }^{\circ} \mathrm{C}$. The resultant $\mathrm{CO}_{2}$ and $\mathrm{N}_{2}$ gases were separated and analyzed using an interfaced Europa 20:20 continuous-flow isotope ratio mass spectrometer (Europa Scientific) Results were reported in delta notation in parts per thousand $(\% o)$ relative to air $\left(\delta^{15} \mathrm{~N}\right)$ and Vienna Pee Dee Belemnite $\left(\delta^{13} \mathrm{C}\right)$.

We did not extract lipids as variance in carbon isotopes due to lipid fractionation $(\sim 0.4-0.5 \%$, greater variance for piscivorous birds; reviewed in ${ }^{43}$ ) is much lower than spatial variation within our study population (chick $\mathrm{SD}=2.04 \%$; egg $\mathrm{SD}=1.96 \% 0)$. We only considered correlations between contaminants and $\delta^{13} \mathrm{C}$, not the absolute value of $\delta^{13} \mathrm{C}$, so consistent depletion of ${ }^{13} \mathrm{C}$ in yolk would make no difference in the strength of correlations. We did not use $\mathrm{C}: \mathrm{N}$ ratios or lipid content to account for variation in $\delta^{13} \mathrm{C}$ because there was no correlation between $\delta^{13} \mathrm{C}$ and $\mathrm{C}: \mathrm{N}$ or percent lipids across the data set of within each lake $(p>0.3)$. Furthermore, the correlation coefficient between the lipid-corrected $\delta^{13} \mathrm{C}$ values ${ }^{44}$ and the nonlipid-corrected $\delta^{13} \mathrm{C}$ values was 0.96 , and using the lipid-corrected values did not change any of our selected models.

We did not measure baseline levels of $\delta^{15} \mathrm{~N}$ at each water body. Variation in baseline levels measured from two snail species within mountain lakes in western Canada $(\mathrm{SD}=0.77 \%$ o and $0.80 \%$; range $=1.64 \%$ and $1.88 \%$; S. Lord, Pers. comm.) were about one-third the variation within our osprey population ( $\mathrm{SD}=1.83$ (feathers), 1.61 (egg); range $=6.8$ (chick), 6.6 (egg)), suggesting that most variation was due to factors other than interlake baselines. Furthermore, provided the baselines were not correlated with levels of the various POPs, variation due to baselines would insert random noise that would increase variance without changing the direction of the relationship.

Statistical Analysis. We used Akaike Information Criterion (AIC) in statistical package SAS version 9.2 (Proc GLM) to examine models that included lipid content, isotopic $\left(\delta \mathrm{N}^{15}\right.$, $\delta \mathrm{C}^{13}$ ) abundance, Henry's law constant and $\log K_{\mathrm{ow}}$ (see next paragraph) and all geographic (watershed area, water body type and area, of glaciers within a watershed and elevation) as explanatory variables and DDE, PCB, HCB (hexachlorobenzene), chlordane, and toxaphene variables as response variables. ${ }^{45}$ We completed separate analyses for eggs, nestling plasma and adult plasma. We log-transformed all contaminant values and all values below the detection limit were assumed to be equal to half the detection limit.

To examine whether variation in the chemical properties of the PCB and OC (organochlorine) congeners was reflected in the geographic distribution of the different congeners, we conducted a redundancy analysis (RDA) in SYNTAX 2000 (Scientia, Budapest, Hungary) to describe patterns in OCs and PCBs among eggs and chicks. RDA is a constrained form of multivariate multiple regression. It is positioned between principal components analysis (PCA) and individual multiple regressions of the dependent variables. RDA is a constrained version as the underlying dimensions in the dependent variables are forced to be multiple linear regressions of the independent variables. ${ }^{46}$ Monte Carlo permutations are run in a stepwise procedure to select predictor variables which best explain variance in the response variables. An ordination diagram is produced where dependent variables are indicated by points, and independent variables as vectors, both of which represent different gradients in the data. The importance of variables in the data set is described by the vector's length or 
Table 2. Results from General Linear Models Examining Variation in Concentrations of Five Contaminant Groups in Nestling Plasma of Ospreys from Western Canada ${ }^{a}$

\begin{tabular}{|c|c|c|c|c|}
\hline contaminant & nestling plasma & nestling plasma & egg & egg \\
\hline & model variables & $\begin{array}{l}\Delta \mathrm{cAIC} \text { (null in } \\
\text { brackets) }\end{array}$ & model variables & $\begin{array}{l}\Delta \mathrm{AIC}_{\mathrm{c}} \text { (null in } \\
\text { brackets) }\end{array}$ \\
\hline$\Sigma \mathrm{DDT}^{\mathrm{b}}$ & elevation + lipid $+\delta^{15} \mathrm{~N}+\delta^{13} \mathrm{C}$ & $0.00(34.1)$ & $\begin{array}{l}\text { glacial area + lake size }+ \text { watershed size }+ \\
\delta^{13} \mathrm{C}\end{array}$ & $0.00(15.3)$ \\
\hline$\Sigma \mathrm{PCBs}^{\mathrm{b}}$ & lake size $+\delta^{15} \mathrm{~N}+\delta^{13} \mathrm{C}$ & $0.00(15.8)$ & elevation + lake area + lipid $+\delta^{13} \mathrm{C}$ & $0.00(17.3)$ \\
\hline $\mathrm{HCB}$ & $\begin{array}{l}\text { lipid + watershed + glacial area + lake size + } \\
\delta^{15} \mathbf{N}\end{array}$ & $0.00(14.5)$ & watershed area + lipid $+\delta^{13} \mathrm{C}$ & $0.00(24.9)$ \\
\hline$\sum$ chlordanes $^{\mathrm{b}}$ & watershed size & $0.00(8.52)$ & watershed area + lipid $+\mathrm{dN}$ & $0.00(11.1)$ \\
\hline toxaphene & glacial area $\times$ watershed size & $0.00(0.87)$ & elevation + lake area + lipid $+\delta^{13} \mathrm{C}$ & $0.00(18.2)$ \\
\hline
\end{tabular}

${ }^{a} \Delta \mathrm{AIC}_{\mathrm{c}}$ values for the null and most parsimonious model are shown. Other models can be found in the SI.

distance from the origin for points. Variables are positively correlated if points and vectors are in the same direction. If at right angles, there is zero effective relationship. Pointing in opposite directions indicates negative correlations. To avoid variation below the detection level confounding our results, we included only those PCBs and OCs that had $>70 \%$ of the data points greater than the detection level. We calculated $\mathrm{RDA}$ axes one to five by using $\delta^{15} \mathrm{~N}, \delta^{13} \mathrm{C}$, percent lipids and the topographic features as the "environmental variables" to constrain the RDA and each PCB or OC as the dependent variables. We then correlated each of the axes with three measures of chemical properties: Henry's law constant $(H)$, volatility $(v)$ and $\log K_{\text {ow }^{*}}{ }^{47,48}$

Essential geographic variables, stable isotopes in plasma, and contaminant levels in eggs and plasma are summarized in Table 1.

Isotopic Composition. Trophic level, $\delta^{15} \mathrm{~N}$, and carbon source, $\delta^{13} \mathrm{C}$, were factors in all of the best models $(\triangle \mathrm{AIC}<$ 1.0, Table 2, Supporting Information (SI) Tables S1 and S2) for most contaminants in both plasma and egg samples, indicating the importance of variation in prey sources. Based on plasma samples, individual ospreys feeding at higher trophic levels accumulated greater concentrations of measured contaminants. $\Sigma$ DDT, for example, correlated positively with $\delta^{15} \mathrm{~N}$, and adults had contaminant concentrations of about an order of magnitude higher at a given trophic level than their chicks (Figure 2). In eggs, only toxaphene was positively correlated with $\delta^{13} \mathrm{C}$ (SI Figure S2)..

Geographic Variation. Broad geographic factors explained much of the variation in contaminant profiles. Samples collected in Alberta, southern BC and northern BC clustered together within the RDA. For the nestling data set, the first axis represented $55 \%$ of the variation and the second axis represented $26 \%$ of the variation, with all other axes representing $<8 \%$ of the variation (Figure 3a). Thus, we considered only the first two axes. Within the egg data set, the first axis represented $78 \%$ of the variation and the second axis represented $11 \%$ of the variation, with all other axes representing $<5 \%$ of the variation, so again we considered only the first two axes (Figure $3 b$ ).

Both $\log K_{\mathrm{ow}}$ and the Henry's law coefficient correlated strongly with RDA axes 1 and 2 for nestlings (SI Figure S3). In contrast, there was no relationship for eggs (all $r^{2}$ values $<0.05$ and $P>0.6$ for all combinations of $\mathrm{H}, \log K_{\mathrm{ow}}$ and RDA axes 1-3).

Limnologic and Topographic Factors. For nestling plasma data, water body type was included in the best models $(\Delta \mathrm{AIC}<1.0)$ for the five main POPs (Table 2). Contaminant

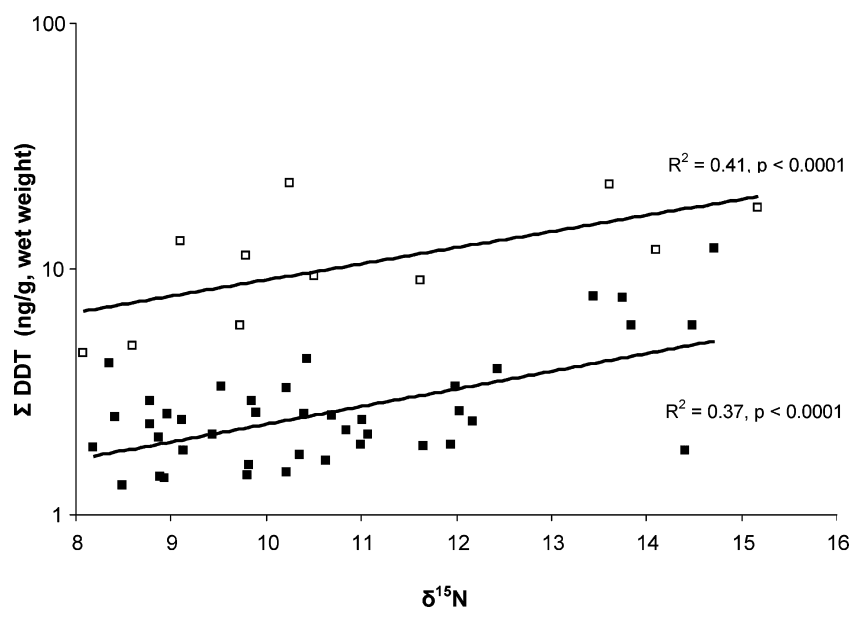

Figure 2. DDT plasma concentrations (ng/g, wet weight) increased with trophic level for both adult (open) and nestling (filled) osprey plasma from Western Canada ( $p<0.0001$ in both cases).

concentrations in plasma were lower in osprey samples from nests on rivers than lakes or reservoirs, and we removed river nests from analyses. For $\Sigma$ DDT, the best single-factor model was trophic level, with elevation, carbon source, the proportion of glaciers within a watershed, percent lipids and the size of lakes relative to overall watershed size were all included in the most parsimonious models (SI Table S1; Figure S1a). The best model for PCBs included lake area, trophic level and aquatic input, while glacier and watershed area factored into the models with $\mathrm{AIC}<1.0$. Best models for other compounds are provided for nestling plasma in SI Table S1.

For nestlings, contaminant concentrations were positively related to elevation and glacial area; watershed area played a lesser role. Compounds with higher $K_{\text {ow }}$, such as PCB 187, tended to be negatively associated with lake area and positively associated with elevation. Compounds with lower $K_{\mathrm{ow}}$, such as $\mathrm{HCB}$ and lower chlorinated PCBs tended to be more closely associated with large lakes, low elevation and high percent lipids. Notably, lower chlorinated PCBs such as CBs-28, -52, and -70 , which have lower $K_{\text {ow }}$, also were negatively associated with elevation and glacial area.

Because the sample size $(n=11)$ was small for adults, we never considered models with more than two variables. Elevation and trophic level were the most parsimonious variables for $\Sigma$ DDT $\left(r^{2}=0.48\right)$. Percent lipids and aquatic input were the most parsimonious variables for PCBs $\left(r^{2}=\right.$ $0.87)$. Percent lipids and elevation were the most parsimonious variables for toxaphene $\left(r^{2}=0.44\right)$ and chlordane $\left(r^{2}=0.66\right)$. 


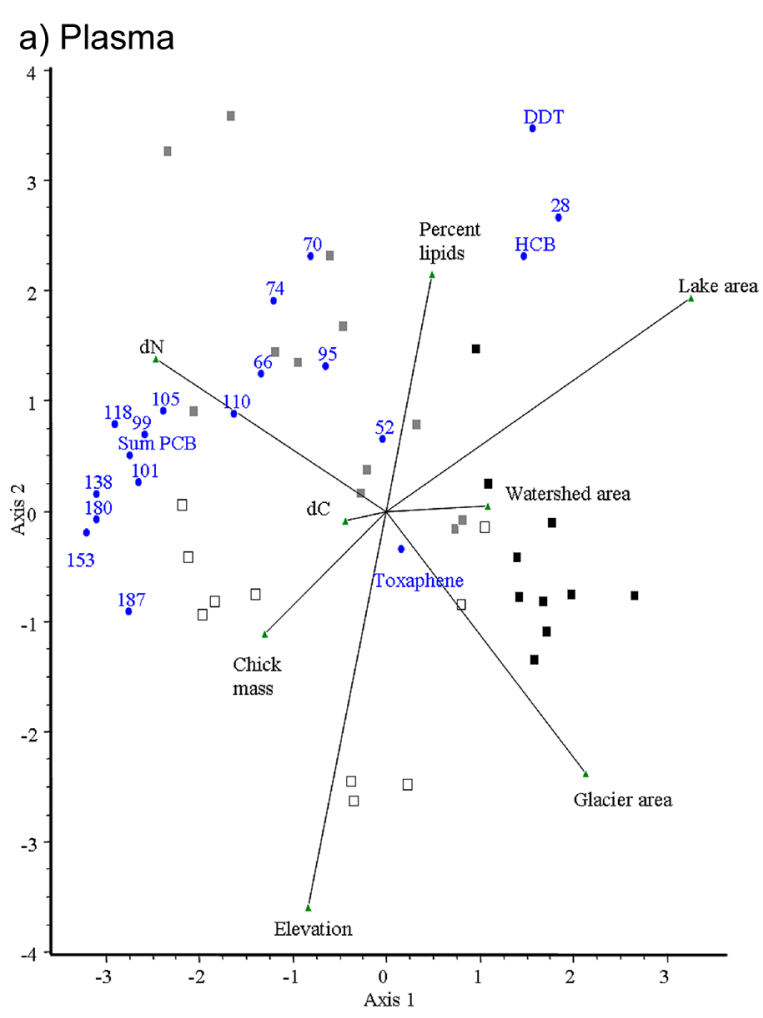

b) Eggs

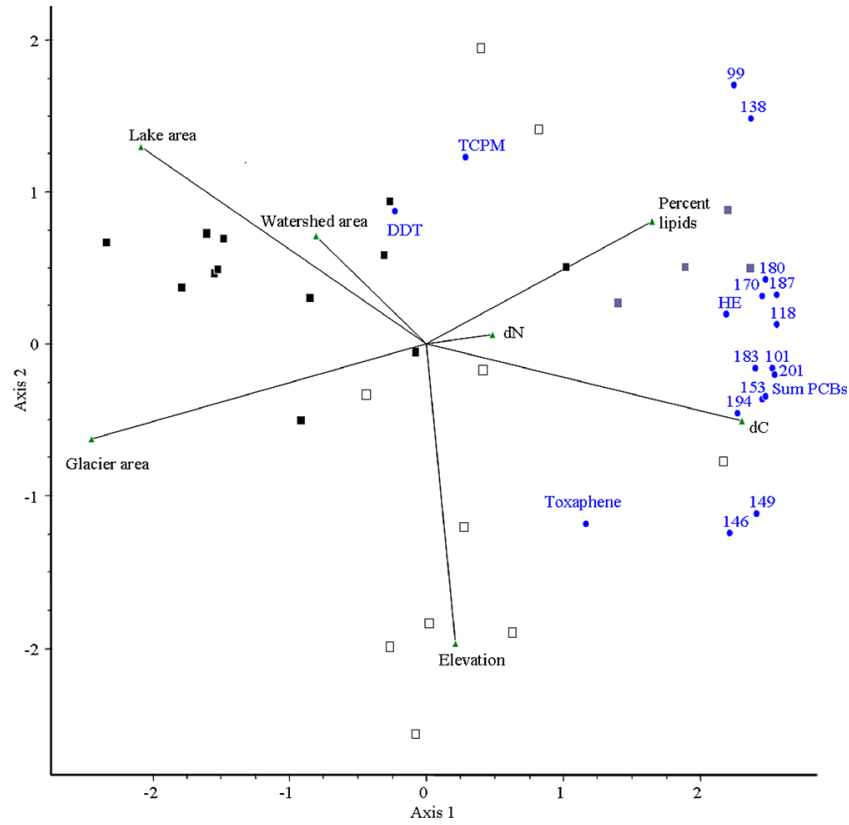

Figure 3. RDA (redundancy analysis) of POPs in (a) nestling plasma and (b) eggs relative to environmental variables. Open symbols are samples collected in Alberta, gray symbols are samples collected in southern BC and dark symbols are samples collected in northern BC.

and tended to decrease with glacial area and lake area (Table 2).

For egg samples, water body type also was included in the best models for all contaminants (SI Table S2). Lipid content of eggs was the best single-factor model for chlordane $\left(r^{2}=\right.$ $0.17)$, toxaphene $\left(r^{2}=0.33\right)$, and $\mathrm{HCB}\left(r^{2}=0.15\right)$, whereas the ratio of watershed size to lake size was the best single-factor model for r-DDT $\left(r^{2}=0.04\right)$. Lake area was the best single factor for PCB $\left(r^{2}=0.13\right)$. The residuals of toxaphene on $\delta^{13} \mathrm{C}$ decreased significantly with lake area (SI Figure S2).

Compounds with higher $K_{\text {ow }}$, such as PCB 146, PCB 149, and toxaphene, tended to be negatively associated with lake area and positively associated with elevation. Compounds with lower $K_{\text {ow }}$ including the less chlorinated PCBs, tended to be positively associated with larger lakes. In general, the hydrophobic and less volatile contaminants with lower $K_{\text {ow }}$ were influenced by variation in lipid content, and were more common at large lakes at low elevations. All contaminants, with the exception of toxaphene, in eggs were negatively associated with glacial area.

\section{DISCUSSION}

We began this investigation with the ambition to sample ospreys over a wide altitudinal gradient as had been done for abiotic variables and fish in both earlier ${ }^{5,13,14,16,20,21}$ and more recent studies. ${ }^{10-12,15}$ Ospreys and nests were reported for a number of higher altitude lakes across the region; subsequent surveys failed, however, to confirm active breeding at many sites. It was evident that at higher elevation lakes in western Canada, including some sampled for fish in previous studies, ${ }^{13,14,49}$ the summer was too short to enable successful breeding by osprey or other avian top predators. Thus, we refocused efforts on lower altitude lakes and catchments with substantial portions of alpine and glaciated terrain.

Given the geographic and topographic expanse of this study, more than $1500 \mathrm{~m}$ in altitude, $2500 \mathrm{~km}$ in latitude, $1000 \mathrm{~km}$ of longitude and orders of magnitude variation in size of water bodies and drainage basins, we would expect ecologic and limnologic variability to be comparable. Anthropogenic factors such as impoundments and introduction of non-native game fishes ${ }^{50}$ have further modified the food chains of these systems. Thus the prey available and taken by ospreys varied considerably. At a subset of six of the study sites, fish taken by osprey during the chick rearing period ranged from lower trophic level benthic feeding cyprinids to predatory pelagic feeding salmonids. ${ }^{51}$ We know that osprey diet and foraging sites also may vary during the breeding season ${ }^{24,25,28}$ and from our own detailed work on another alpine bird, the American dipper (Cinclus mexicanus), ${ }^{48}$ which probably accounts for some of the variation in exposure between contaminants in eggs and nestling plasma. Nonetheless and despite those many and disparate sources of variability, measurement of $\delta^{15} \mathrm{~N}$ in particular and to a lesser extent $\delta^{13} \mathrm{C}$ provided a quantitative integration of diet differentials and explained some of the patterns in contaminant exposure of osprey, as we had hypothesized previously. ${ }^{24,25,28}$ We successfully applied this approach to a previous assessment of mercury in these same ospreys $^{27}$ and to studies of American dippers in alpine systems, ${ }^{34,52}$ as have other researchers for studies of fish and invertebrates in some of our study sites. ${ }^{15,49}$

Accounting for dietary variation from isotopic composition, there were some general patterns in the data. HCB, chlordane, and $\Sigma$ PCBs decreased with watershed size; toxaphene, $\Sigma D D T$ and HCB decreased with watershed size divided by lake size. Thus, there were lower levels of contamination in relatively small lakes draining areas of large watersheds, contrary to our predictions that such lakes would be contaminant sinks for large watersheds. Perhaps water in lakes that are closer in size to their watersheds has longer residence time, and thus those lakes accumulate more contaminants than lakes that are smaller relative to their watershed, which may act as intermediates 
flowing into larger lakes. There are few similar data sets, certainly with avian species, with which to compare. Within a single watershed, concentrations of total OC pesticides and $\Sigma$ PCBs increased significantly with drainage area in eggs of American dippers. ${ }^{53}$ In contrast, previous examination of PCB loadings and bioaccumulation in predatory fish over a wide range of geographic and limnologic conditions found relationships to be complex and unpredictable. Paterson et al, ${ }^{54}$ for example, found neither systematic associations between lake size and PCB concentrations or evidence of strong biomagnifications up the food chain in fish, nor among PCB concentrations in various matrices with other physical, chemical, or biotic conditions at the time of sampling. Similar complex patterns and few systemic relationships were reported in a survey of POPs in predatory fish from European alpine lakes. ${ }^{55}$ Given that we are able to discern relations, even if correlations were not always that strong, perhaps attests to the value of using a terrestrial sentinel such as the osprey, where POPs exposure is determined almost totally by dietary intake, to examine trends in POPs loadings over broad spatial scales.

Our RDA analysis indicated a decrease in the proportion of lower chlorinated PCBs (CBs 28-99), HCB and DDT with elevation and glacial area, related to variation in $\mathrm{K}_{\mathrm{ow}}$ and Henry's law constant, also evident from the RDA. Despite the potential for some confounding local inputs on hydro-electric reservoirs, that result was in reasonable accord with the prediction by Wania and Westgate. ${ }^{2}$ Their determination was consistent with data for fish in some studies of European mountains of a relative increase in more chlorinated PCBs such as CBs-138 and 153 at higher elevations, the result of more efficient altitudinal cold trapping of those heavier compounds. ${ }^{2,17,49}$

SDDT decreased significantly in osprey tissues with elevation and with amount or proportion of glacial cover within the watershed, probably at least in part due to local contaminant inputs at lower elevations, an issue raised by Daly and Wania ${ }^{56}$ for fish studies. Local contaminant sources, for example of DDT used in the fruit growing south Okanagan region, including exposure of osprey was discussed in more detail in previous papers. ${ }^{24,25,28,42,51}$

Toxaphene, which was never used as an insecticide in western Canada, was the one compound found at greater concentrations in osprey samples at higher elevation drainages with more coverage by permanent snow and ice. Toxaphene was used as a piscicide prior to stocking game fish at some lakes within the study areas. However, the distinctive 2-exo,3-endo,5exo,6-endo,8,9,10-heptachlorobornane (B7-1001; Hp-Sed) congener pattern found in fish from treated lakes ${ }^{57}$ was not evident in osprey samples which were dominated by congeners such as B8-1412 and Parlars 40-50, strongly indicative of atmospheric loadings. Elevated concentrations of toxaphene in osprey samples from higher elevation lakes from the Rocky Mountains were consistent with findings in fish. ${ }^{57}$

The potential for release of POPs stored in ice fields and glaciers to rivers and lakes has been examined by a number of researchers. ${ }^{11-17}$ Glacial meltwater is routed rapidly to surface waters after being canalized on the glacial surface. Such runoff may be enriched with entrained POPs because the meltwater has minimal contact with catchment soils and sediments, creating little opportunity for POPs to dissipate through evaporation and binding to organic-poor glacial sediments. ${ }^{11,13,14}$ For example, POPs increased with altitude in snow collected at high alpine lakes of the Canadian Rockies ${ }^{5}$ and POPs were about an order of magnitude higher in biota samples from glacially fed compared to nonglacially fed lakes in the Italian Alps. ${ }^{11,12}$ Toxaphene, increased 1000-fold over a $1500 \mathrm{~m}$ change in altitude in the Canadian Rockies. $5,13,16,21$

However, our examination of spatial variability does not support a glacial input hypothesis for osprey, as we did not find greater contamination in lakes draining areas with larger proportions of glacial coverage and at higher elevations, as reported for abiotic components. ${ }^{11,13,14}$ Data for fish and other biota are more complex than water or sediments with the influence of factors such as growth dilution ${ }^{15}$ and food chain structure/resource partitioning, ${ }^{49}$ although the studies of Italian lakes certainly support the role of glacial melting as an important source of POPs to biota. ${ }^{11,12,58-61}$ We observed the reverse pattern; with the exception of toxaphene, we found generally lower POPs in higher elevation and more glaciated drainages.

Longer term temporal trends in glacial extent may also be a factor. Globally, following more than a century of retreat, during the 1950 s to early 1970 s coinciding with the 'organochlorine (OC) era', there was a period of glacial expansion when on balance POPs and other contaminants were presumably accumulating in glacial ice and snow (SI Figure S4). Donald et al. ${ }^{16}$ sampled ice strata deposited over the period 1959 to 1995 from a glacial ice mass on Snow Dome Mountain at $3300 \mathrm{~m}$ elevation in the Canadian Cordillera. They reported a 10 year delay in maximum flux to this high elevation ice mass relative to depositional trends in eastern North America, probably influenced by trans-Pacific POPs transport, ${ }^{31}$ and concluded that glacial meltwater would continue to contribute significant quantities of organochlorine pesticides into alpine ecosystems for at least decades and perhaps centuries. In SI Figure S4, we combined temporal trends in global glacial mass with POPs use and deposition to the Canadian Rockies. Therefore, the material melting out of a typical glacier over our study period (1999-2003) would date from at least a century previous, well prior to the OC era. The POPs era, however, may have been extended even into the early 1990s by ongoing usage in Asia and elsewhere. ${ }^{31}$

We recognize that accounting by glacial input by a simple calculation of area covered by year-round snow and ice is a simplification. Glaciers have both a horizontal and vertical component constituting the mass of the glacier and the dynamics of melting and runoff are complex and variable, ${ }^{62}$ and are only part of the overall hydrological mass balance of the watershed. Other factors, particularly deposition of black carbon, may also be accelerating glacial melt by reducing snow albedo, ${ }^{63}$ and influencing POPs deposition, accumulation and availability. ${ }^{64}$

In contrast to our simple reconstruction of glacial melt, Bogdal et al. ${ }^{10}$ modeled the dynamics of POPs release from a Swiss glacier. Their model predicted significant POPs increases during the early 1990s, and lower inputs later in that decade. Those predictions are coincident with the apparent temporal trends we see in ospreys, indicating that previous glacial melting may have been a factor influencing contaminant trends in western Canada. During the early 1990s, concentrations of DDE and chlordane were elevated in osprey eggs across British Columbia, including several of the present sites. ${ }^{65}$ More than $25 \%$ of sampled eggs exceeded the toxicity threshold of $4.2 \mu \mathrm{g} /$ $\mathrm{g}$, and the spatial pattern was not explained by known local sources and partially prompted use of satellite telemetry to examine wintering sources. ${ }^{24}$ The rapid melting of glacial ice 
during the 1980s and 1990s combined with the decadal delay in POPs flux reported by Donald et al. ${ }^{16}$ may have released substantial DDE and other POPs to osprey food chains. In the present data from 1999 to 2003, only one of 88 eggs exceeded $4.2 \mu \mathrm{g} / \mathrm{g}$.

The decline in concentrations of $\Sigma \mathrm{DDT}$ and $\mathrm{PPCB}$ in osprey eggs over the period 1991 to 2003 at one of our monitoring sites is shown in SI Figure S4. Kamloops is a river location which does integrate runoff from the surrounding alpine drainage basin. Henny et al. ${ }^{66}$ also reported significant declines in DDE, other OC pesticides and PCBs, 1997-2004, in osprey eggs from the lower Columbia River. Such decreasing concentrations of DDTs, PCBs, and other chlorinated hydrocarbons in British Columbia ospreys would have been principally due to the regulatory restrictions on usage imposed during the 1970s and early 1980s in North America (ref 65, SI Figure S4). Previously, we documented significant decreases in egg burdens of chlorinated dioxin and furan compounds in osprey eggs downstream of pulp and paper mills, subsequent to voluntary and regulatory changes in pulp bleaching processes. ${ }^{24}$ However, given the substantial area covered in permanent snow and ice in many of the drainages studied here, and the timing of documented recession of glacial area (refs 6,7,62, SI Figure S4), the possibility of further dilution of contaminants by input of large volumes of relatively clean meltwater during the 1980 s to 1990s should not be discounted.

Bogdal et al. ${ }^{10}$ predicted a further influx during the current decade of glacial bound contaminants to receiving waters, but we do not have samples to test that prediction for western Canada. Overall, the coincidence with the osprey data is interesting and would merit further sampling particularly at a site where features were similar to the Oberaar glacier. The influence of glacial meltwater on POPs contamination of alpine lakes also is likely more apparent at lower trophic levels and over smaller spatial scales, and could vary substantially among and within alpine regions, depending on variability in factors such as finer scale POPs deposition patterns and glacial melting trends. We plan to examine data on POPs in fish selected by osprey as prey and collected from a subset of the lakes in the present study.

Further regarding the toxicological implications of the exposure levels of the compounds measured in this study, not only have the DDE levels decreased over the decade of the previous study, but other chemicals also were below effect levels. Variation in reproductive success at six of the sites were examined in more detail and related to energetics as measured by rates of prey delivery to nests. ${ }^{51}$

In summary, relatively simple models involving watershed and lake size, elevation, and the percent of year-round snow and ice explained much of the variation in contaminant levels in ospreys. The effect of geography was most evident in the finding of lower contaminant levels in ospreys breeding along rivers, as contaminants do not accumulate readily in active fluvial systems. We suggest that similar GIS and environmental chemistry models could be used to predict contamination levels at continental or even global scales, provided they also factor in ecology and physiology of organisms.

\section{ASSOCIATED CONTENT}

\section{S Supporting Information}

More details about the chemical analytical methods, water body and osprey summary data, and results of data analyses. This material is available free of charge via the Internet at http:// pubs.acs.org.

\section{AUTHOR INFORMATION}

\section{Corresponding Author}

*E-mail: john.elliott@ec.gc.ca.

\section{Notes}

The authors declare no competing financial interest.

\section{ACKNOWLEDGMENTS}

M. Conner, A. Elliott, H. Gill, G. Kardosi, M. Machmer, C. Steeger, S. Weech, L. Wilson, and especially S. Lee Ortiz assisted with trapping and handling of ospreys in British Columbia. Staff of BC Hydro and West Kootenay Power-D. Williams (Merritt), K. Brown, D. Hamp, B. Morris, V. Bidnyk (Golden), G. Peterson, V. Gerlib, K. Curly (Nakusp), R. Royer, J. Pickard, E. Marback, P. Quaedvlieg, R. Sherbinin (Oliver)assisted in accessing nests, as did J. Oseychuk, A. Palmer, T. Tal, R. Hobbis, M. Martin, and S. Oleman. R. McNeil, and L. Hemsen coordinated preparation, storage and shipping of samples in Ottawa. B. Wakeford and A. Idrissi supervised or conducted the pesticide and PCB analyses, with the exception of toxaphene which was conducted by. B. Wilkinson. Funding was provided mainly by the Toxic Substance Research Initiative of Environment Canada.

\section{REFERENCES}

(1) Wania, F.; Mackay, D. Global fractionation and cold condensation of low volatility organochlorine compounds in polar regions. Ambio 1993, 22, 10-18.

(2) Wania, F.; Westgate, J. N. 2008. On the mechanism of mountain cold-trapping of organic chemicals. Environ. Sci. Technol. 2008, 42, 9092-9098.

(3) Franz, T. P.; Eisenreich, S. J. Snow scavenging of polychlorinated biphenyls and polycyclic aromatic hydrocarbons in Minnesota. Environ. Sci. Technol. 1988, 32, 771-1778.

(4) Norstrom, R. J.; Simon, M.; Muir, D. C. G.; Schweinsburg, R. E. Organochlorine contaminants in arctic marine food chains: Identification, geographical distribution, and temporal trends in polar bears. Environ. Sci. Technol. 1988, 22, 1063-1071.

(5) Blais, J. M.; Schindler, D. W.; Muir, D. C. G.; Kimpe, L. E.; Donald, D. B.; Rosenberg, B. Accumulation of persistent organochlorines in mountains of western Canada. Nature 1998, 395, 585588.

(6) Haeberli, W.; Frauenfelder, R.; Hoelzle, M.; Maisch, M. Rates and acceleration trends of global glacier mass changes. Geogr. Ann. A 1999, $81,585-591$.

(7) Dyurgerov, M. B.; Meier, M. F. Twentieth century climate change: Evidence from small glaciers. Proc. Nat. Acad. Sci. 2000, 97, $1406-1411$.

(8) Macdonald, R. W.; Harner, T.; Fyfe, J. Recent climate change in the Arctic and its impact on contaminant pathways and interpretation of temporal trend data. Sci. Total Environ. 2005, 342, 5-86.

(9) Borga, K.; Saloranta, T. M.; Ruus, A. Simulating climate changeinduced alterations in bioaccumulation of organic contaminants in an arctic marine food web. Environ. Toxicol. Chem. 2010, 29, 1349-1357.

(10) Bogdal, C.; Nikolic, D.; Luthi, M. P.; Schenker, U.; Scheringer, M.; Hungerbuhler, K. Release of legacy pollutants from melting glaciers: Model evidence and conceptual understanding. Environ. Sci. Technol. 2010, 44, 4063-4069.

(11) Bettinetti, R.; Quadroni, S.; Galassi, S.; Bacchetta, R; Bonardi, L.; Vailatai, G. Is meltwater from alpine glaciers a secondary DDT source for lakes? Chemosphere 2008, 73, 1027-1031.

(12) Bizzotto, E. C.; Villa, S.; Vaj, C.; Vighi, M. Comparison of glacial and non-glacial-fed streams to evaluate the loading of persistent 
organic pollutants through seasonal snow/ice melt. Chemosphere 2009, 74, 924-930.

(13) Blais, J. M.; Schindler, D. W.; Sharp, M.; Braekevelt, F.; Lafreniere, M.; Muir, D. C. G. Fluxes of semi-volatile organochlorines in Bow Lake, a remote high altitude, glacier-fed subalpine Lake in the Canadian Rocky Mountains. Limnol. Oceanogr. 2001, 46, 2019-2031.

(14) Blais, J. M.; Schindler, D. W.; Muir, D. C. G.; Sharp, M.; Donald, D. B.; Lafreniere, M.; Braekevelt, E.; Comba, M.; Backus, S. Glaciers are a dominant source of persistent organochlorines to a subalpine Lake in Banff National Park, Canada. Ambio 2001, 30, 410.

(15) Demers, M. J.; Kelly, R. N.; Blais, J. M.; Pick, F. R.; St. Louis, V. L.; Schindler, D. W. Organochlorine compounds in trout from lakes over a 1600 meter elevation gradient in the Canadian Rocky Mountains. Environ. Sci. Technol. 2007, 41, 2723-2729.

(16) Donald, D. B.; Syrgiannis, J.; Crosley, R. W.; Holdsworth, G.; Muir, D. C. G.; Rosenberg, B.; Sole, A.; Schindler, D. W. Delayed deposition of organochlorine pesticides at a temperate glacier. Environ. Sci. Technol. 1999, 33, 1794-1798.

(17) Grimalt, J. O.; Fernández, P.; Berdie, L.; Vilanova, R. M.; Catalan, J.; Psenner, R.; Hofer, R.; Appleby, P. G.; Rosseland, B. O.; Lien, L.; Massabuau, J. C.; Battarbee, R. W. Selective trapping of organochlorine compounds in mountain Lakes of temperate areas. Environ. Sci. Technol. 2001, 35, 2690-2697.

(18) Muir, D. C. G.; Ford, C. A.; Grift, N. P.; Metner, P. A.; Lockhart, W. L. Geographic variation of chlorinated hydrocarbons in burbot (Lota lota) from remote lakes and rivers in Canada. Arch. Environ. Contam.Toxicol. 1990, 19, 530-542.

(19) Houde, M.; Muir, D. C. G.; Kidd, K. A.; Guildford, S.; Drouillard, K. G.; Evans, M. S.; Wang, X.; Whittle, D. M.; Haffner, D.; Kling, $\mathrm{H}$. Influence of lake characteristics on the biomagnification of persistent organic pollutants in lake trout food webs. 2008, 27, 21692178.

(20) Donald, D. B.; Bailey, R.; Crosley, D.; Muir, D. C. G.; Shaw, P.; Syrgiannis, J. Polychlorinated biphenyls and organochlorine pesticides in the aquatic environment along the continental divide region of Alberta and British Columbia; Environment Canada, Water Quality Branch, Regina, SK, Canada, 1993.

(21) Kidd, K. A.; Schindler, D. W.; Muir, D. C. G.; Lockhart, W. L.; Hesslein, R. H. High concentrations of toxaphene in fishes from a subarctic Lake. Science 1995, 269, 240-242.

(22) Braune, B. M.; Donaldson, G. M.; Hobson, K. A. Contaminant residues in seabird eggs from the Canadian Arctic. II. Spatial trends and evidence from stable isotopes for intercolony differences. Environ. Pollut. 2002, 117, 133-45.

(23) Genualdi, S. A.; Killin, R. K.; Woods, J.; Wilson, G. N.; Schmedding, D.; Simonich, S. M. 2009.Trans-Pacific and regional atmospheric transport of polycyclic aromatic hydrocarbons and pesticides in biomass burning emissions to western North America. Environ. Sci. Technol. 2009, 43, 1061-1066.

(24) Elliott, J. E.; Machmer, M. M.; Henny, C. J.; Wilson, L. K.; Norstrom, R.J.. Contaminants in ospreys from the Pacific Northwest: I. Trends and patterns in polychlorinated dibenzo-p-dioxins and dibenzofurans in eggs and plasma. Arch. Environ. Contam. Toxicol. 1998, 35, 620-631.

(25) Elliott, J. E.; Morrissey, C. A.; Henny, C. J.; Inzunza, E. R.; Shaw, P. Satellite telemetry and prey sampling reveal contaminant sources to Pacific Northwest ospreys. Ecol. Appl. 2007, 17, 12231233.

(26) Henny, C. J.; Grove, R. A.; Kaiser, J. L. Osprey distribution, abundance, reproductive success and contaminant burdens along lower Columbia River, 1997/1998 Versus 2004. Arch. Environ. Contam. Toxicol. 2008, 54, 525-534.

(27) Guigueno, M. F.; Elliott, K. H.; Levac, J.; Wayland, M.; Elliott, J. E. Differential exposure of alpine ospreys to mercury: Melting glaciers, hydrology or deposition patterns? Environ. Internat. 2012, 40, 24-32.

(28) Elliott, J. E.; Wilson, L. K.; Henny, C. J.; Trudeau, S. F.; Leighton, F. A.; Kennedy, S. W.; Cheng, K.M . Assessment of biological effects of chlorinated hydrocarbons in osprey chicks. Environ. Toxicol. Chem. 2001, 20, 866-879.
(29) Henny, C. J.; Kaiser, J. L.; Grove, R. A.; Johnson, B. L.; Letcher, R. J. Polybrominated diphenyl ether flame retardants in eggs may reduce reproductive success of ospreys in Oregon and Washington, USA. Ecotoxicology 2009, 18, 802-813.

(30) Grove, R. A.; Henny, C. J. Osprey: Worldwide sentinel species for assessing and monitoring environmental contamination in rivers, lakes, reservoirs and estuaries. J. Toxicol. Environ. Health, Part B 2009, $12,25-44$.

(31) Toschik, P. C.; Rattner, B. A.; McGowan, P. C.; Christman, M. C.; Carter, D. B.; Hale, R. C.; Matson, C. W.; Ottinger, M. A. Effects of contaminant exposure on reproductive success of ospreys (Pandion haliaetus) nesting in the Delaware River and Basin, USA. Environ. Toxicol. Chem. 2009, 24, 617-628.

(32) Hebert, C. E.; Shutt, J. L.; Norstrom, R. J. Dietary changes cause temporal fluctuations in polychlorinated biphenyl levels in herring gull eggs from Lake Ontario. Environ. Sci. Technol. 1997, 31, 1012-7.

(33) Bustnes, J. O.; Erikstad, K. E.; Bakken, V.; Mehlum, F.; Skaare, J. $\mathrm{U}$. Feeding ecology and the concentration of organochlorines in glaucous gulls. Ecotoxicology 2000, 9, 179-86.

(34) Morrissey, C. A.; Bendell-Young, L. I.; Elliott, J. E. Linking contaminant profiles to the diet and breeding location of American dippers using stable isotopes. J. Appl. Ecol. 2004, 41, 502-12.

(35) Elliott, K. H.; Cesh, L. S.; Dooley, J. A.; Letcher, R. J.; Elliott, J. E. PCBs and DDE, but not PBDEs, increase with trophic and marine input in nestling bald eagles. Sci. Total Environ. 2009, 407, 3867-3875.

(36) Canada 3D:Product Standard; Natural Resources Canada: Sherbrooke, PQ 2001.

(37) North American Atlas-Glaciers; Natural Resources Canada: Sherbrooke, PQ, 2001.

(38) Jenson, S. K.; Domingue, J. O. Extracting topographic structure from digital Elevation data for geographic information system analysis. Photogramm. Eng. Remote Sens. 1998, 54, 1593-1600.

(39) Strahler, A. N. Quantitative analysis of watershed geomorphology. Trans. Am. Geophy. Union 1957, 8, 913-920.

(40) Mark, D. M. Network models in geomorphology. In Modelling in Geomorphological Systems; John Wiley: New York, NY, 1988.

(41) Tarboton, D. G.; Bras, R. L.; Rodriguez-Iturbe, I. On the extraction of channel networks from digital elevation data. Hydrol. Processes 1991, 5, 81-100.

(42) Elliott, J. E.; Martin, P. A.; Arnold, T. W.; Sinclair, P. H. Organochlorines and reproductive success of birds in orchard and non-orchard areas of central British Columbia, 1990-91. Arch. Environ. Contam. Toxicol. 1994, 26, 435-443.

(43) Becker, B. H.; Newman, S. H.; Inglis, S.; Beissinger, S. R. Dietfeather stable isotopes $(\delta 15 \mathrm{~N}$ and $\delta 13 \mathrm{C})$ fractionation in common murres and other seabirds. Condor 2007, 109, 451-456.

(44) Post, D. M.; Layman, C. A.; Arrington, D. A.; Takimoto, G.; Quattrochi, J.; Montana, C. G. Getting to the fat of the matter: Models, methods and assumptions for dealing with lipids in stable isotope analyses. Oecologia 2007, 152, 179-189.

(45) Yang, Y. 2005. Can the strengths of AIC and BIC be shared? A conflict between model identification and regression estimation. Biometrika 2003, 92, 937-950.

(46) Data Analysis in Community and Landscape Ecology; Jongman, R. H. G., ter Braak, C. J. F., van Tongeren, O. F. R., Eds.; Cambridge University Press: Cambridge, UK, 1995

(47) Shiu, W. Y.; Mackay, D. A critical review of aqueous solubilities, vapor pressures, Henry's law constants, and octanol-water partition coefficients of the polychlorinated biphenyls. J. Phys. Chem. Ref. Data 1986, 15, 911-929.

(48) Portolillo, J.; Eganhouse, R. P. The Search for Reliable Aqueous Solubility $\left(S_{w}\right)$ and Octanol-Water Partition Coefficient $\left(K_{o w}\right)$ Data for Hydrophobic Organic Compounds: DDT and DDE as a Case Study; U.S. Geological Survey Water Resources Investigation Report, 2001; pp 01-4201.

(49) Campbell, L. M.; Schindler, D. W.; Donald, D. B.; Muir, D. C. G. Organochlorine transfer in the food web of subalpine Bow Lake, Banff National Park. Can. J. Fish. Aquat. Sci. 2000, 57, 1258-1269. 
(50) Schindler, D. W.; Parker, B. R. Biological pollutants: Alien fishes in mountain lakes. Water, Air, Soil Pollut.: Focus 2002, 2, 379-397.

(51) Morrissey, C. A.; Kardosi, G.;, L.K.: Elliott, J. E. Effect of food supply and contaminants on osprey productivity in southern British Columbia, Canada. In Raptors Worldwide; ChancellorR. D., Meyburg, B. -U., Eds.; Birdlife Hungary: Budapest, Hungary, 2004. .

(52) Morrissey, C. A.; Elliott, J. E.; Ormerod, S. J. Diet shifts during egg laying: Implications for measuring contaminants in bird eggs. Environ. Pollut. 2010, 158, 447-454.

(53) Morrissey, C. A.; Bendell-Young, L. I.; Elliott, J. E. Contributions from atmospheric deposition to food chain biomagnification in the Chilliwack watershed of British Columbia, Canada. Environ. Sci. Technol. 2005, 39, 8090-8098.

(54) Paterson, M. J.; Muir, D. C. G.; Rosenberg, B.; Fee, E. J.; Anema, C.; Franzin, W. Does lake size affect concentrations of atmospherically derived polychlorinated biphenyls in water, sediment, zooplankton, and fish? Can. J. Fish. Aquat. Sci. 1998, 55, 544-553.

(55) Rognerud, S.; Grimwalt, J. O.; Rosseland, B. O.; Fernandez, P.; Hoffer, R.; Lackner, R.; Lauritzen, B.; Lien, L.; Massabuau, J. C.; Ribes, A. Mercury and organochlorine contamination in brown trout (Salmo trutta) and arctic char (Salvelinus alpinus) from high mountain lakes in Europe and the Svalbard archipelago. Wat. Air Soil Pollut. 2002, 2, 209-232.

(56) Daly, G. L.; Wania, F. Organic contaminants in mountains. Environ. Sci. Technol. 2005, 39, 409-420.

(57) Donald, D. B.; Stern, G. S.; Muir, D. C. G.; Fowler, B. F.; Miskimmin, B. M.; Bailey, R. Chlorobornanes in water, sediment, and fish from toxaphene treated and untreated lakes in Western Canada. Environ. Sci. Technol. 1998, 32, 1391-1397.

(58) Gallego, E.; Grimalt, J. O.; Bartrons, M.; Lopez, J. F.; Camerero, L.; Catalan, J.; Stuchlik, E.; Battarbee, R. Altitudinal gradients of PBDEs and PCBs in fish from European high mountain lakes. Environ. Sci. Technol. 2007, 41, 2196-2202.

(59) Carrera, G.; Fernández, P.; Vilanova, R. M.; Grimalt, J. O. Persistent organic pollutants in snow from European high mountain areas. Atmos. Environ. 2001, 35, 245-254.

(60) Carrera, G.; Fernández, P.; Grimalt, J. O.; Ventura, M.; Camarero, L.; Catalan, J.; Nickus, U.; Thies, H.; Psenner, R. Atmospheric deposition of organochlorine compounds to remote high mountain Lakes of Europe. Environ. Sci. Technol. 2002, 36, 25812588.

(61) Villa, S.; Vighi, M.; Maggi, V.; Finizio, A.; Bolzacchini, E. Historical trends of organochlorine pesticides in an alpine glacier. $J$. Atmosp. Chem. 2003, 46, 295-311.

(62) Moore, R. D.; Demuth, M. N. 2001. Mass balance and streamflow variability at Place Glacier, Canada, in relation to recent climate fluctuations. Hydrol. Process 2001, 15, 3473-3486.

(63) Xu, B.; Cao, J.; Hansen, J.; Yao, T.; Joswia, D. R.; Wang, N.; Wu, G.; Wang, M.; Zhao, H.; Yang, W.; Liu, A.; He, J. Black soot and survival of Tibetan glaciers. Proc. Nat. Acad. Sci. 2009, 106, 2211422118.

(64) Koelmans, A. A.; Jonker, M. T. O.; Cornelissen, G.; Bucheli, T. D.; Van Noort, P. C. M.; Gustafsson, O. Black carbon: The reverse of its dark side. Chemosphere 2006, 63, 365-377.

(65) Elliott, J. E.; Wilson, L. K.; Henny, C. J.; Machmer, M. M. Contaminants in ospreys from the Pacific Northwest: II. Patterns and trends in organochlorine pesticides, polychlorinated biphenyls and mercury in eggs and plasma. Arch. Environ. Contam. Toxicol. 2000, 38, 93-106.

(66) Henny, C. J.; Grove, R. A.; Kaiser, J. L. Osprey distribution, abundance, reproductive success and contaminant burdens along Lower Columbia River, 1997/1998 versus 2004. Arch. Environ. Contam. Toxicol. 2008, 54, 525-534. 